DOI: https://doi.org/10.31933/jimt.v2i5

Received: 25 Maret 2021, Revised: 25 Mei 2021, Publish: 13 Juni 2021

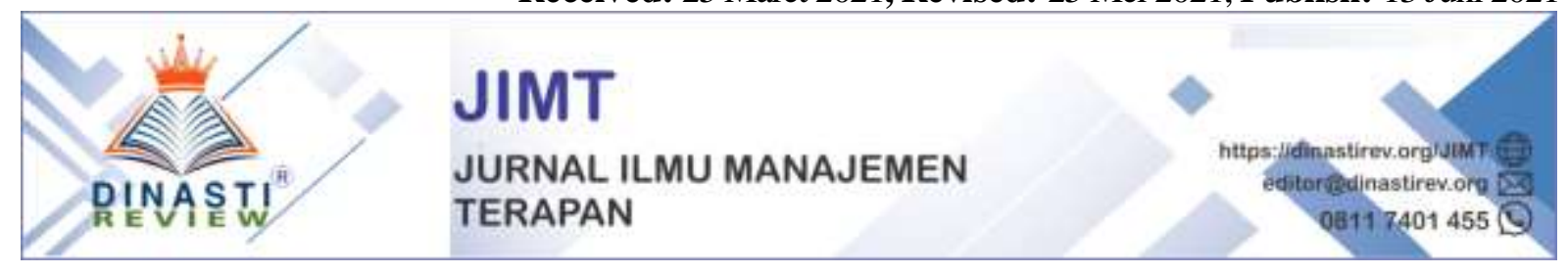

\title{
DETERMINASI NILAI PELANGGAN DAN KEPUTUSAN \\ PEMBELIAN: ANALISIS KUALITAS PRODUK, DESAIN PRODUK DAN ENDORSE
}

\author{
Vicky Brama Kumbara ${ }^{1}$ \\ ${ }^{1}$ Student of Doctor Management, Universitas Putra Indonesia YPTK Padang \\ Vickybrama@upiyptk.ac.id
}

\begin{abstract}
Abstrak: Penelitian ini bertujuan untuk melihat seberapa besar Determinasi Nilai Pelanggan dan keputusan pembelian, dengan melakukan analisis terhadap kualitas produk, desain produk dan endorse produk, dari hasil analisis dapat disimpulkan bahwa masih banyak faktor lain yang mempengaruhi nilai pelanggan dan keputusan pembelian, selain dari kualitas produk dan desain produk pada semua tipe dan level organisasi atau perusahaan.
\end{abstract}

Kata Kunci: Nilai Pelanggan, Keputusan Pembelian, Kualitas Produk, Desain Produk Dan Endorse.

\section{PENDAHULUAN}

\section{Latar Belakang Masalah.}

Setiap mahasiswa baik Strata 1, Strata 2 dan Strata 3, di wajibkan untuk melakukan riset dalam bentuk skripsi, tesis dan disertasi. Begitu juga bagi dosen, peneliti dan tenaga fungsional lainya aktif melakukan riset dan memubuat artikel ilmiah untuk di publikasi pada jurnal-jurnal ilmiah.

Berdasarkan pengalaman empirik banyak mahasiswa dan dosen muda juga peneliti lainnya, kesulitan untuk mencari artikel pendukung dalam riset sebagai penelitian terdahulu atau sebagai penelitian yang relevan. Artikel sebagai peneliti yang relevan di perlukan untuk memperkuat teoti yang di teliti, untuk melihat hubungan antar variable dan membangun hipotesis, juga sangat diperlukan pada bagian pembahasan hasil penelitian.

Artikel ini membahas pengaruh kualitas produk, desain produk dan endorse terhadap nilai pelanggan dan dampaknya terhadap keputusan pembelian, (Suatu Studi Literatur Manajemen Pemasaran). Tentu tidak semua faktor yang mempengaruhi keputusan pembelian dan nilai pelanggan pada artikel ini, ini hanya sebagian kecil saja yang akan di kaji dan di review. 
Secara rinci tujuan dari penulisan "Literature Review Paper" ini adalah mengetahui pengaruh antara variabel exogen kualitas produk, desain produk, endorse dan nilai pelanggan terhadap variabel endogen keputusan pembelian.

1) Pengaruh kualitas produk terhadap nilai pelanggan

2) Pengaruh kualitas produk terhadap keputusan pembelian

3) Pengaruh desain produk terhadap nilai pelanggan

4) Pengaruh desain produk terhadap keputusan pembelian

5) Pengaruh endorse produk terhadap nilai pelanggan

6) Pengaruh endorse produk terhadap keputusan pembelian

7) Pengaruh nilai pelanggan terhadap keputusan pembelian

8) Pengaruh kualitas produk terhadap keputusan pembelian melalui nilai pelanggan

9) Pengaruh desain produk terhadap keputusan pembelian melalui nilai pelanggan

10) Pengaruh endorse terhadap keputusan pembelian melalui nilai pelanggan

\section{KAJIAN TEORI}

\section{Keputusan Pembelian}

Keputusan pembelian adalah suatu alasan yang mendorong bagaimana konsumen untuk melakukan pilihan terhadap pembelian suatu produk sesuai yang dibutuhkan. Menurut (Fandy Tjiptono 2016:22) perilaku konsumen merupakan tindakan-tindakan yang secara langsung terlibat dalam usaha memperoleh, menentukan produk dan jasa, termasuk proses pengambilan keputusan yang mendahului dan mengikuti tindakan-tindakan tersebut. konsumen harus melalui seluruh urutan tahap ketika membeli produk. Khususnya karena dalam model ini menampung seluruh pertimbangan yang muncul ketika konsumen menghadapi pembelian baru dengan keterliban yang lebih tinggi.

Sebelum memutuskan untuk membeli suatu produk, seorang konsumen pada dasarnya melakukan proses pengambilan keputusan terlebih dahulu. Proses pengambilan keputusan dalam (Agusta 2020:12) merupakan tahapan konsumen dalam memutuskan suatu produk tertentu yang menurutnya sudah paling baik dari berbagai alternatif sesuai denagn kepentingan-kepentingan tertentu dengan menetapkan pilihan yang dianggap paling menguntungkan. Proses pemilihan dan penilaian ini biasanya diawali dengan mengidentifikasi masalah utama yang mempengaruhi tujuan, menyusun, menganalisis dan memilih berbagai alternatif tersebut dan mengambil keputusan yang dianggap paling baik. Sedangkan menurut (Kotler dan Armstrong 2015) keputusan pembelian konsumen adalah membeli merek yang paling disukai, tetapi dua faktor bisa berada antara niat pembelian dan keputusan pembelian. Dimana mengetahui masalahnya, informasi produk ataupun merek produk tersebut dan melakukan evaluasi sehingga dapat memecahkan masalah sehingga dapat mengarah kepada keputusan pembelian

Keputusan pembelian merupakan sikap dalam membeli atau menggunakan suatu produk yang menurut konsumen memberikan kepuasan ataupun resiko yang mungkin ada terjadi. Menurut (Schiffman dan Kanuk 2015) keputusan pembelian adalah pemilihan dari dua atau lebih alternatif pilihan keputusan pembelian, artinya bahwa seseorang dapat 
membuat keputusan, harus tersedia beberapa alternatif pilihan. Keputusan untuk membeli dapat mengarah pada bagaimana proses dalam pengambilan keputusan tersebut itu dilakukan.

Menurut (Kotler dan Armstrong 2017:180) keputusan pembelian adalah keputusan pembeli tentang merek mana yang dibeli. Proses pengambilan keputusan yang rumit sering melibatkan beberapa keputusan. Keputusan ini melibatkan pilihan antara dua atau lebih alternatif. Keputusan pembelian konsumen adalah tahap dimana konsumen juga mungkin membentuk niat untuk membeli produk yang paling disukai, dimana keputusan konsumen untuk memodifikasi, menunda, atau menghindar sangat dipengaruhi resiko yang dirasakan.

Dari uraian di atas dapat disimpulkan bahwa keputusan pembelian merupakan sikap konsumen dalam menentukan suatu pemilihan suatu produk untuk mencapai kepuasan yang di inginkan. Perilaku ini adalah sebuah kegiatan konsumen dalam memutuskan pembelian dalam menggunakan produk yang tetap, jika ada perubahan yang terjadi terhadap produk tersebut, maka konsumen melakukan keputusan pembelian kembali.

\section{Proses Keputusan Pembelian}

Produsen harus dapat melihat faktor yang dapat mempengaruhi perilaku konsumen dan pemahaman tentang cara konsumen melakukan keputusan pembelian. Menurut (Kotler 2017) ada lima tahap yang dilalui konsumen dalam mengambil keputusan pembelian:

\begin{tabular}{|c|c|c|c|c|}
\hline $\begin{array}{c}\text { Pengenalan } \\
\text { Masalah }\end{array}$ & $\begin{array}{l}\text { Pencarian } \\
\text { Informasi }\end{array}$ & $\begin{array}{l}\text { Evaluasi } \\
\text { Alternatif }\end{array}$ & $\begin{array}{l}\text { Keputusan } \\
\text { Pembelian }\end{array}$ & $\begin{array}{l}\text { Perilaku } \\
\text { Pasca } \\
\text { Pembelian }\end{array}$ \\
\hline
\end{tabular}

\section{Gambar 1 Model Proses Pengambilan Keputusan}

Sumber: Menurut (Kotler 2017)

a. Pengenalan Masalah

Proses dimulai saat pembeli menyadari adanya masalah atau kebutuhan. Pembeli merasakan adanya perbedaan antara yang nyata dan yang diinginkan. Kebutuhan ini disebabkan karena adanya rangsangan internal maupun eksternal.

b. Pencarian Informasi

Seorang konsumen yang terdorong kebutuhannya mungkin, atau mungkin juga tidak, mencari informasi lebih lanjut. Jika dorongan konsumen kuat dan produk itu berada di dekatnya, mungkin konsumen langsung membelinya. Jika tidak, kebutuhan konsumen ini hanya menjadi ingatan saja.

c. Evaluasi Alternatif

Konsumen memproses informasi tentang pilihan merek untuk membuat keputusan terakhir. Pertama, kita melihat bahwa konsumen mempunyai kebutuhan. Konsumen mencari manfaat tertentu dan selanjutnya melihat kepada atribut produk. Konsumen memberikan bobot yang berbeda untuk setiap atribut produk sesuai dengan kepentingannya.

d. Keputusan Pembelian 
Pada tahap evaluasi, konsumen menyusun merek-merek dalam himpunan pilihan serta membentuk niat pembelian. Biasanya konsumen memilih merek yang disukai. Tetapi ada pula faktor yang mempengaruhi seperti sikap orang lain dan faktor-faktor keadaan yang tidak terduga.

e. Perilaku Sesudah Pembelian

Sesudah pembelian terhadap suatu produk, konsumen mengalami beberapa tingkat kepuasan atau ketidakpuasan.

\section{Indikator Keputusan Pembelian}

Dalam penelitian ini menggunakan empat indikator untuk menentukan keputusan pembelian yang diambil dari (Kotler 2018:70), yaitu:

a. Kemantapan pada sebuah produk

Dalam melakukan pembelian, konsumen memilih salah satu dari beberapa alternatif yang ada. Pilihan tersebut didasarkan pada kualitas, mutu, harga yang terjangkau, dan faktorfaktor lain yang dapat memantapkan keinginan konsumen untuk membeli produk apakah produk tersebut benar- benar ingin digunakan atau dibutuhkan.

b. Kebiasaan dalam membeli produk

Kebiasaan konsumen dalam membeli produk juga berpengaruh terhadap keputusan pembelian. Konsumen merasa produk tersebut sudah terlalu melekat di benak mereka karena mereka sudah merasakan manfaat dari produk tersebut. Oleh karena itu, konsumen merasa tidak nyaman jika mencoba produk baru dan harus menyesuaikan diri lagi. Mereka cenderung memilih produk yang sudah biasa digunakan.

c. Memberikan rekomendasi kepada orang lain

Dalam melakukan pembelian, jika konsumen mendapatkan manfaat yang sesuai dengan sebuah produk, mereka pasti merekomendasikan produk tersebut dengan orang lain. Mereka ingin orang lain juga merasakan bahwa produk tersebut sangat bagus dan lebih baik dari produk lain.

\section{Faktor yang mempengaruhi keputusan pembelian}

Menurut (Kotler 2015) Sikap konsumen dalam membeli sesuatu yang dipengaruhi oleh beberapa faktor, yaitu:

a. Faktor Budaya

Budaya merupakan penentu keinginan dan perilaku paling dasar. Pemasaran lintas budaya muncul dari riset pemasaran yang cermat, yang menyingkap bahwa relung etnis dan demografik yang berbeda tidak selalu menanggapi dengan baik iklan pasar massal.

b. Faktor Sosial

Dalam faktor sosial, perilaku konsumen dipengaruhi oleh faktor - faktor sosial seperti kelompok acuan, keluarga, serta peran dan status sosial.

1. Kelompok Acuan 
Kelompok acuan seseorang terdiri dari semua kelompok yang memiliki pengaruh langsung (tatap muka) atau tidak langsung terhadap sikap atau perilaku orang tersebut. Kelompok yang berpengaruh langsung dinamakan kelompok keanggotaan, seperti keluarga, teman, tetangga, dan rekan kerja yang berinteraksi secara terus - menerus. Kelompok tidak langsung seperti keagamaan, profesi, dan asosiasi perdagangan yang membutuhkan interaksi tidak begitu rutin.

2. Keluarga

Keluarga merupakan organisasi pembelian konsumen yang paling penting dalam masyarakat dan para anggota keluarga menjadi kelompok acuan primer yang paling berpengaruh. Orientasi keluarga terdiri dari orang tua dan saudara kandung yang mendapatkan orientasi atas agama, politik, dan ekonomi serta ambisi pribadi, harga diri, dan cinta. Pengaruh yang lebih langsung terhadap perilaku pembelian sehari - hari adalah keluarga prokreasi yaitu, pasangan dan anak seseorang.

3. Peran dan Status sosial

Seseorang berpartisipasi dalam banyak kelompok, keluarga, klub, dan organisasi sepanjang hidupnya. Posisi seseorang dalam masing - masing kelompok dapat didefinisikan dalam peran dan status. Peran terdiri dari kegiatan yang diharapkan dilakukan seseorang sesuai dengan orang - orang disekitarnya. Masing - masing peran membawa status yang mencerminkan nilai umum yang diberikan kepadanya oleh masyarakat.

c. Faktor Pribadi

Keputusan pembeli juga dipengaruhi oleh karakteristik pribadi. Karakteristik tersebut meliputi usia dan tahap dalam siklus hidup, misalnya pekerjaan, keadaan ekonomi, kepribadian dan konsep diri, serta nilai dan gaya hidup pembeli. meliputi usia, pekerjaan, gaya hidup dan kepribadian.

d. Faktor Psikologi

Satu perangkat proses psikologis berkombinasi dengan karakteristik konsumen tertentu untuk menghasilkan proses keputusan pembelian. Tugas pemasar adalah memahami apa yang terjadi dalam kesadaran konsumen antara datangnya rangsangan pemasaran luar dan keputusan pembelian akhir. Empat proses psikologis penting yaitu motivasi, persepsi, pembelajaran, dan memori secara fundamental memengaruhi tanggapan konsumen terhadap berbagai rangsangan pemasaran

Ada beberapa yang dapat mempengaruhi perilaku konsumen terhadap keputusan pembelian menurut (Swastha dan Handoko 2020) menyatakan bahwa perilaku konsumen dipengaruhi oleh faktor-faktor berikut:

a. Pencetus

Orang yang pertama kali menyadari adanya keinginan atau kebutuhan yang belum terpenuhi dan mengusulkan ide untuk membeli suatu barang atau jasa tertentu.

b. Pemberi Pengaruh

Orang yang memberi pandangan, nasihat, atau pendapat sehingga dapat membantu keputusan pembelian.

c. Pengambil Keputusan 
Orang yang menentukan keputusan pembelian, apakah jadi membeli, apa yang dibeli, bagaimana cara membeli, atau dimana membelinya.

d. Pembeli

Adalah orang yang akan membeli yang sesungguhnya, pengenalan kebutuhan informasi produk berbagai informasi keputusan pembelian.

e. Pemakai

Orang yang mengkonsumsi atau menggunakan barang atau jasa yang telah dibeli.

Keputusan pembelian sudah banyak di teliti oleh peneliti sebelumnya di antaranya oleh (Yu et al., 2013), (Ali, 2019a), (Rosyid et al., 2013), (Kazmi \& Mehmood, 2016), (Sivaram et al., 2019), (Chovanová et al., 2015) (Durrani et al., 2015) (Foster, 2017). (Suhaily, 2017) (Dudu \& Agwu, 2014), (Anggita \& Ali, 2017), (Novansa \& Ali, 2017), (Brata et al., 2017), (Djatmiko \& Pradana, 2016), (Gan \& Wang, 2017), (Yunita \& Ali, 2017), (Rosyid et al., 2013) (Rödiger et al., 2016), (Amanah et al., 2017),(Konuk, 2018), (Ferdinand, 2014)(Larasetiati \& Ali, 2019), (Firmansyah \& Ali, 2019), (Zhao et al., 2019), (Jeaheng et al., 2020), (Damghanian et al., 2016), (Al-ekam, 2016), (Yen, 2019).

\section{Nilai Pelanggan}

Nilai dapat didefinisikan sebagai rasio antara banyaknya yang diperoleh pelanggan dan banyaknya yang diberikan pelanggan, pelanggan mendapatlan manfaat dan mengeluarkan biaya (Kotler 2018:13). Konsumen akan membeli dari produsen yang di yakini menawarkan nilai yang dipikirkan tertinggi, nilai yang dipikirkan oleh konsumen yaitu selisih antara evaluasi atas semua manfaat serta biaya tawaran yang diberikan oleh produsen. Dimana keuntungan yang dirasakan adalah kombinasi dari atribut fisik, jasa dan teknik pendukung dalam pemanfaatan produk.

(Rangkuti 2015:13) mendefinisikan nilai sebagai pengkajian secara menyeluruh manfaat dari suatu produk, didasarkan persepsi pelanggan atas apa yang telah diterima oleh pelanggan dan yang telah diberikan oleh produk tersebut. Nilai dapat mencerminkan sejumlah manfaat, baik yang berwujud maupun yang tidak berwujud. Nilai juga dianggap sebagai suatu kombinasi dalam kualitas, pelayanan dan harga yang disebut juga dengan tiga elemen nilai pelanggan. Dari definisi-definisi tersebut dapat disimpulkan bahwa nilai pelanggan adalah hal yang menyangkut pendapat seseorang dengan mempertimbangkan atas manfaat serta pengorbanan yang didapati selama memiliki hingga merasakan suatu barang atau jasa tersebut.

Kualitas jasa/layanan adalah pemahaman yang cukup dari peusahaan tentang pelanggan agar mampu menciptakan nilai bagi pelanggan secara terus-menerus. Produsen tidak hanya menyampaikan produk dari tangan produsen ketangan konsumen. Tetapi produsen pun harus bisa memperhatikan apakah kebutuhan dan keinginan konsumen terpenuhi, apakah konsumen puas terhadap produk tersebut. Dengan itu maka produsen dapat memenuhi nilai yang dimaksud konsumen dan dengan begitu akan mendorong mereka untuk terus melakukan pembelian berulang terhadap produknya.

Menurut (Kotler dalam Hurriyati 2017) nilai pelanggan adalah sekumpulan manfaat yang diharapkan oleh pelanggan dari produk atau jasa tertentu dan biaya pelanggan total adalah 
sekumpulan biaya yang diharapkan oleh konsumen yang dikeluarkan untuk mengevaluasi, mendapatkan, menggunakan dan membuang produk atau jasa. Dan hubungan yang diinginkan adalah hubungan yang bersifat jangka panjang, sebab usaha dan biaya yang dikeluarkan oleh perusahaan diyakini jauh lebih besar apabila harus menarik pelanggan baru atau pelanggan yang sudah meninggalkan perusahaan, daripada mempertahankannya.

Menurut (Zeithmal dan Biner 2016) menyampaikan bahwa terdapat beberapa cara yang tepat untuk menetapkan harga produk berdasarkan defenisi nilai untuk pelanggan, yaitu :

a. Value is low price. Value adalah harga murah. Konsumen mempersepsikan bahwa suatu produk atau jasa bernilai jika menetapkan harga yang rendah atau jasa yang murah.

b. Value is everything I want in a service. Value adalah segala sesuatu yang diinginkan konsumen dalam produk atau jasa. Harga yang ditetapkan bukan merupakan hal yang utama selama konsumen mendaptkan apa yang diinginkan dari produk atau jasa.

c. Value is quality I get for the price I pay. Value adalah kualitas yang diterima konsumen dari harga yang dibayarkan. Sebagian konsumen melihat nilai sebagai suatu pertukaran yang seimbang antara uang yang dibayarkan dengan kualitas dari produk atau jasa yang didapatkan.

d. Value is all that I get from all that I give. Value ialah apa yang diperoleh dari apa yang diberikan. Akhirnya konsumen menganggap bahwa segala keuntungan yang diperoleh seperti uang, waktu, dan usaha dapat menjelaskan arti dari nilai itu sendiri

\section{Dimensi Nilai Pelanggan}

Nilai dari setiap merek ataupun jasa merupakan bahwa aset yang bernilai bagi produsem untuk dapat meningkatkan minat konsumen untuk melakukan keputusan pembelian atas suatu produk. Apakah sesudah membeli kemudian saat penggunaan konsumen bisa saja membayangkan nilai yang didapatkan. Menurut (Sweeney 2015) terdapat beberapa dimensi dalam membentuk nilai pelanggan yaitu :

a. Nilai Emosional

Merupakan nilai yang timbul dari kemampuan produk untuk menimbulkan perasaan atau emosi pada diri konsumen stetelah mengunakan suatu produk,

b. Nilai Sosial

Merupakan nilai yang diperoleh dari manfaat suatu produk untuk meningkatkan konsep diri sosial konsumen. Semakin tinggi penilaian konsumen maka semakin tinggi pula tingkat kepuasan yang diterima oleh konsumen

c. Nilai Kualitas

Merupakan nilai didapatkan dari persepsi konsumen terhadap kualitas pelayanan dan kinerja yang di harapkan atas produk tersebut Sehingga produsen harus memperhatikan seluruh aspek yang ada sehingga konsumen dapat memberikan nilai yang positif tergadap perusahaan.

d. Nilai Harga 
Merupakan nilai yang didapat dari harga yang telah di keluarkan dengan apa yang didapatkan oleh konsumen.

\section{Tipe-Tipe Nilai Pelanggan}

Menurut (Sheth dan Mittal 2019) bahwa tipe-tipe nilai pelanggan terdapat 9 kategori yaitu:

a. Performane Value

Kualitas fisik produk dari penggunaan suatu produk. tipe nilai yang mencerminkan kemampuan suatu produk atau jasa dalam melaksanakan fungsi fisiknya secara konsisten.

b. Social Value

Suatu manfaat produk dalam rangka memuaskan konsumen agar mendapatkan pengakuan dan kebanggaan secara sosial.

c. Emotional Value

Kepuasan secara emosional yang diperoleh dari menggunakan atau mengkonsumsi suatu produk.

d. Price Value

Harga atau biaya yang berkaitan dengan upaya mendapatkan suatu produk.

e. Credit Value

Dimana konsumen terbebas dari keharusan membayar pembelian dalam waktu singkat.

f. Financial Value

Penawaran syarat pada saat pembayaran yang lebih longgar dan terjangkau.

g. Service Value

Berupa bantuan yang diharapkan konsumen yang berkaitan dengan kepuasan pelanggan dalam pembelian produk atau jasa.

h. Conveniece Value

Berupa penghematan waktu dan usaha yang dibutuhkan dalam memperoleh suatu produk

i. Personalization Value

Menerima produk yang disesuaikan dengan kondisi konsumen dan memberikan kesan yang baik.

\section{Indikator Nilai Pelanggan}

(Sheth dkk 2020) menjelaskan bahwa nilai pelanggan dibagi menjadi 3 komponen penting, yaitu konsumsi dalam hal nilai kualitas, nilai sosial, nilai emosional. Ketiga dimensi yang paling aspek komprehensif tentang memandang nilai sampai sekarang, sebagai berikut:

a. Nilai Kualitas (Quality value) Nilai kualitas merupakan nilai yang diperoleh dari persepsi pelanggan terhadap kualitas dan kinerja yang diharapkan atas produk atau jasa.

b. Nilai Emosional (Emotional value) Nilai emosional merupakan nilai yang berasal dari kemampuan produk untuk menimbulkan perasaan positif pada diri konsumen.

c. Nilai Sosial (Social value) Nilai sosial merupakan nilai yang didapatkan dari kemampuan produk untuk meningkatkan konsep diri-sosial konsumen. 
Penelitian tentang Nilai Pelanggan telah banyak dikaji oleh penelitian sebelumnya seperti penelitian yang dikembangkan oleh (Brata et al., 2017), (Al-ekam, 2016), (Setiawan et al., 2020), (Amanah et al., 2017), (Yen, 2019), (Jeaheng et al., 2020), (Konuk, 2018), (Suhaily, 2017), (Susanty et al., 2016), (Dudu \& Agwu, 2014), (Anggita \& Ali, 2017), (Djatmiko \& Pradana, 2016), (Gan \& Wang, 2017), (Yunita \& Ali, 2017), (Rosyid et al., 2013), (Rödiger et al., 2016), (Ferdinand, 2014)

\section{Kualitas Produk}

Kualitas dapat diartikan kemampuan dari produk untuk menjalankan fungsinya yang mencakup daya tahan, kehandalan atau kemajuan, kekuatan, kemudahan dalam pengemasan dan reparasi produk dan ciri-ciri lainnya (Luthfia 2016) Setiap produsen harus dapat tingkat produk yang dihasilkan sehingga dapat membantu atau menunjang usaha untuk meningkatkan ataupun mempertahankan produk dipasar sasarannya. Mengingat kualitas produk memiliki kaitan dengan keputusan konsumen yang merupakan tujuan produsen dari kegiatan pemasaran yang dilakukan. Yang menurut (Schiffman dan Kanuk 2019) bahwa kualitas produk adalah kemampuan suatu perusahaan untuk memberikan identitas atau fitur pada setiap produk sehingga konsumen dapat mengenali produk tersebut.

Menurut (Philip Kotler 2015) Kualitas produk merupakan ciri dan karakteristik suatu barang atau jasa yang berpengaruh pada kemampuannya untuk memuaskan kebutuhan yang dinyatakan maupun tersirat. Kualitas merupakan hal yang penting bagi para produsen yang harus diusahakan agar produk yang dihasilkan dapat bersaing di pangsa pasar, ini dikarenakan pada saat ini konsumen lebih teliti memilih dalam mendapatkan suatu produk yang memberikan kepuasan yang diinginkan. Konsumen selalu ingin mendapatkan produk yang berkualitas sesuai harga yang dibayarkan.

Kualitas yang tinggi juga dapat berarti konsistensi tingkatan kualitas yang tinggi. Dalam konsisten yang tinggi tersebut kualitas produk berarti kualitas kesesuaian yaitu bebas dari kecacatan dan kekonsistenan dalam memberikan tingkatan kualitas yang dicapai atau dijanjikan. Jadi, dalam prakteknya semua perusahaan harus berusaha keras memberikan tingkatan kualitas kesesuaian yang tinggi. (Kotler dan Armstrong 2016). Produk yang sesuai dengan keinginan yang diharapkan pembeli, menjadi keberhasilan bagi produk yang dijual. Dengan ini produk yang dibuat lebih baik berdasarkan dari minat dan selera konsumen. Kualitas produk menurut (Kotler 2019) adalah keseluruhan ciri dari suatu produk yang berpengaruh pada kemampuan untuk memuaskan kebutuhan yang dinyatakan atau tersirat. Kualitas produk merupakan pengetahuan' tentang nilai suatu produk untuk membedakan dengan produk lain. Dengan ini perusahaan' dapat memfokuskan ke beberapa produknya' agar bisa bersaing untuk memperebutkan dan menarik minat pembeli pada produk yang di jual.

Jika hal itu dapat dilaksanakan oleh perusahaan, maka perusahaan tersebut dapat tetap memuaskan para konsumen dan dapat menambah jumlah konsumen. Dalam perkembangan suatu perusahaan, persoalan kualitas produk ikut menentukan pesat tidaknya perkembangan perusahaan tersebut. Apabila dalam situasi pemasaran yang semakin ketat persaingannya, 
peranan kualitas produk semakin besar dalam perkembangan perusahaan. Selain itu, konsumen menyukai produk yang menawarkan kualitas, kinerja, dan pelengkap inovatif yang terbaik. (Lupiyoadi dan Hamdani 2019:131).

Dari uraian diatas dapat diartikan bahwa kualitas produk adalah tingkatan suaut produk dalam memenuhi nilai dan fungsinya, dalam artian kemampuan suatu produk dalam menjalankan sebagai fungsinya. Dalam sudut pemasaran, kualitas produk diukur dalam ukuran persepsi pembeli tentang kualitas suatu produk tersebut.

\section{Tingkat Produk}

Produk dalam pengertian ekonomi diperkenalkan pertama kali oleh ekonom-politisi menurut Kotler (Kotler 2018:403) ada lima tingkatan produk, yaitu:

a. Core Benefit

Yaitu manfaat dasar dari suatu produk yang ditawarkan kepada konsumen.

b. Basic Product

Yaitu bentuk dasar dari suatu produk yang dapat dirasakan oleh panca indera.

c. Expected Product

Yaitu serangkaian atribut - atribut produk dan kondisi - kondisi yang diharapkan oleh pembeli pada saat membeli suatu produk.

d. Augmented Product

Yaitu sesuatu yang membedakan antara produk yang ditawarkan oleh badan usaha dengan produk yang ditawarkan oleh pesaing.

e. Potential Product

Yaitu semua argumentasi dan perubahan bentuk yang dialami oleh suatu produk dimasa yang akan dating.

\section{Dimensi Kualitas Produk}

Menurut (Mullins 2017) terdapat beberapa dimensi yang mempengaruhi kualitas produk yaitu :

1. Performance (kinerja),

Berhubungan dengan karakteristik operasi dasar dari sebuah produk.

2. Durability (daya tahan),

yang berarti berapa lama atau umur produk yang bersangkutan bertahan sebelum produk tersebut harus diganti. Semakin besar frekuensi pemakaian konsumen terhadap produk maka semakin besar pula daya tahan produk.

3. Conformance to specifications (kesesuaian dengan spesifikasi), Yaitu sejauh mana karakteristik operasi dasar dari sebuah produk memenuhi spesifikasi tertentu dari konsumen atau tidak ditemukannya cacat pada produk.

4. Features (fitur),

Adalah karakteristik produk yang dirancang untuk menyempurnakan fungsi produk atau menambah ketertarikan konsumen terhadap produk. 
5. Reliabilty (reliabilitas),

Adalah probabilitas bahwa produk akan bekerja dengan memuaskan atau tidak dalam periode waktu tertentu. Semakin kecil kemungkinan terjadinya kerusakan maka produk tersebut dapat diandalkan.

6. Aesthetics (estetika),

Berhubungan dengan bagaimana penampilan produk bisa dilihat dari tampak, rasa, bau, dan bentuk dari produk.

7. Perceived quality (kesan kualitas),

Sering dibilang merupakan hasil dari penggunaan pengukuran yang dilakukan secara tidak langsung karena terdapat kemungkinan bahwa konsumen tidak mengerti atau kekurangan informasi atas produk yang bersangkutan.

\section{Indikator Kualitas Produk}

Menurut (Gito Sudarma 2018) mengungkapkan indikator yang dapat digunakan untuk mengukur kualitas produk yaitu:

a. Berbagai macam variasi produk

b. Daya tahan produk

c. Kualitas produk sesuai dengan spesifikasi dari konsumen

d. Penampilan kemasan produk (estetika)

e. Kualitas produk terbaik dibandingkan dengan merek lain

Penelitian tentang Kualitas Produk telah banyak dikaji oleh penelitian sebelumnya seperti penelitian yang dikembangkan oleh (Brata et al., 2017), (Al-ekam, 2016), (Setiawan et al., 2020), (Amanah et al., 2017), (Yen, 2019), (Jeaheng et al., 2020), (Konuk, 2018), (Suhaily, 2017), (Susanty et al., 2016), (Dudu \& Agwu, 2014), (Anggita \& Ali, 2017), (Djatmiko \& Pradana, 2016), (Gan \& Wang, 2017), (Yunita \& Ali, 2017), (Rosyid et al., 2013), (Rödiger et al., 2016), (Ferdinand, 2014)

\section{Desain Produk}

Menurut (Kotler dan Keller 2020) menyatakan desain produk adalah segala fitur yang dimiliki oleh produk yang dapat mempengaruhi keberadaannya. Aspek desain dalam kegiatan pemasaran merupakan salah satu hal yang membuat daya tarik terhadap suatu produk, desain akan menjadi cara yang paling ampuh untuk memposisiskan produk yang dipasarkan. (Anandya 2017) menyatakan bahwa desain produk menjadi pembeda produk suatu merek dengan merek lainnya yang menciptakan ciri khas bagi suatu merek.

Desain juga diartikan sebagai alat manajemen untuk menganalisis hasil kegiatan dan perkembangan yang dilakukan sebelum menjadi strategi yang akan dilakukan produsen dalam hal memproduksi produk yang akan dipasarkan. (Kotler dan Keller 2016) mendefinisikan "Design is the totality of features that affect how a product looks, feels, and functions to a consumer.". Hal itu berarti bahwa desain merupakan totalitas fitur yang mempengaruhi bagaimana sebuah produk terlihat, terasa, dan berfungsi bagi konsumen. Desain menawarkan 
tiga hal: fungsi, estetika dan daya tarik. Lebih lanjut menurut (Kotler dan Armstrong 2019b) desain yang baik mempertimbangkan bentuk eksternal tetapi juga menciptakan produk yang mudah, aman, tidak mahal untuk penggunaan dan layanan, mudah dan ekonomis untuk di produksi dan didistribusikan

Menurut (Pero et al 2018) mengemukakan bahwa desain produk adalah totalitas dari fitur-fitur itu yang mempengaruhi penampilan fisik dan fungsi produk dalam hal kebutuhan konsumen. Desain dikaitkan sebagai suatu kegiatan yang berkaitan dengan proses inovasi produk, perusahaan harus tetap mengembangkan inovasi dalam hal desain supaya dapat menghasilkan produk yang baik dan sesuai dengan keinginan konsumen. Desain yang baik dinilai dengan pemahaman mendalam tentang kebutuhan pelanggan. Lebih dari sekedar menciptakan atribut produk atau jasa, desain melibatkan pembentukan pengalaman pemakaian produk bagi pelanggan. Oleh karena itu, desain produk sebaiknya tidak terlalu memikirkan atribut produk dan spesifikasi teknis yang lebih memikirkan bagaimana cara pelanggan menggunakan dan mengambil manfaat dari produk (Kotler dan Armstrong 2015:274)

Desain atau motif produk merupakan salah satu aspek penting yang bisa membuat konsumen tertarik. Desain atau motif tersebut sangat mendukung atribut produk sehingga produk yang dimiliki mempunyai karakter yang berbeda dari produk yang lain. (Kotler dan Armstrong 2019) Penyederhanaan ataupun peningkatan kualitas produk merupakan salah satu cara penerapan desain atau motif produk. Peningkatan desain produk dapat berupa peningkatan kualitas atau mutu serta peningkatan nilai guna dari produk tersebut. Sedangkan penyederhanaan desain atau motif produk bertujuan agar pemakaian suatu produk menjadi semakin mudah.

\section{Indikator Desain Produk}

Menurut (Azany 2018) indikator yang terkait dengan desain produk:

a. Variasi desain, yaitu desain yang ditawarkan memiliki keragaman dan pilihan untuk menarik minat konumen.

b. Model terbaru, yaitu perkembangan desain yang terbaru agar konsumen tidak bosan terhadap citra merek tersebut.

c. Desain mengikuti trend, yaitu inovasi produsen dalam mengemabngkan desain yang sesuai dengan kemajuan zaman.

\section{Faktor yang Mempengaruhi Desain Produk}

Desain produk terletak pada penetapan secara rinci desain produk yang akan diproduksi, serta sesuai dengan tujuan yang akan di capai. Menurut (Zulian Yamit 2018) Desain produk yang baik perlu memperhatikan beberapa faktor berikut ini :

a. Globalisasi selera konsumen 
Globalisasi konsumen dapat menumbuhkan keinginan produsen untuk membuat barang yang memiliki kesamaan dari segi desain. Anggapan bahwa adanya kesamaan selera konsumen dikebanyakan negara terhadap produk yang sama.

b. Segmentasi pasar

Perlunya produsen melakukan segmentasi pasar yang diakibatkan perbedaan selera konsumen.

c. Kondisi lokal

Pengembangan suatu produk yang didasarkan kondisi lokal atau budaya agar dapat diterima oleh konsumen.

d. Teknologi

Perkembangan teknologi memungkinkan produsen untuk mengembangkan produk yang memiliki desain yang sesuai kemajuan yang ada.

\section{Parameter Desain produk}

Desain produk merupakan totalitas fitur yang mempengaruhi bagaimana produk itu terlihat bagi konsumen. Menurut (Kotler 2015:131-38) terdapat 7 parameter desain produk yaitu:

a. Ciri-ciri

Ciri-ciri adalah karakteristik yang mendukung fungsi dasar produk. Sebagian besar produk dapat ditawarkan dengan beberapa ciri-ciri. Ciri-ciri produk merupakan alat kompetitif untuk produk perusahaan yang terdiferensiasi. Beberapa perusahaan sangat inovatif dalam penambahan ciri-ciri baru ke produknya. karakteristik yang dapat mendukung fungsi dasar dari suatu produk sebagai besar bahwa ciri-ciri merupakan alat yang efektif dalam persaingan pasar bagi produsen.

b. Kinerja

Kinerja mengacu kepada tingkat karakteristik utama produk pada saat beroperasi. Pembeli produk-produk mahal biasanya membandingkan kinerja (kenampakan/prestasi) dari merek-merek yang berbeda. Para pembeli biasanya rela membayar lebih untuk kinerja yang lebih baik sepanjang lebihnya harga tidak melebihi nilai yang dirasakan.

c. Mutu kesesuaian

Yang dimaksud dengan penyesuaian adalah tingkat dimana desain produk dan karekteristik operasinya mendekati standar sasaran. Mutu kesesuaian adalah tingkat kesesuaian dan pemenuhan semua unit yang diproduksi terhadap spesifikasi sasaran yang dijanjikan. Hal ini disebut konformansi karena spesifikasinya.

d. Daya tahan

Daya tahan merupakan ukuran waktu operasi yang diharapkan dari suatu produk tertentu. Sebagai contoh, Volvo mengiklankan mobilnya sebagai mobil yang mempunyai waktu pakai tertinggi untuk menjustifikasi harganya yang lebih tinggi. Pembeli bersedia membayar lebih untuk produk yang lebih tahan lama.

e. Daya Uji

adalah ukuran kemungkinan bahwa suatu produk tidak akan berfungsi salah atau rusak dalam suatu periode waktu tertentu. Pembeli rela membayar lebih untuk produk-produk 
dengan reputasi reliabilatas yang lebih tinggi. Mereka ingin menghindari biaya karena kerusakan dan waktu untuk reparasi.

f. Kemudahan perbaikan

Kemudahan perbaikan adalah suatu ukuran kemudahan perbaikan suatu produk yag mengalami kegagalan fungsi atau kerusakan-kerusakan. Kemudahan perbaikan ideal akan ada jika pemakai dapat memperbaiki produk tersebut dengan biaya murah atau tanpa biaya dan tanpa memakan waktu terlalu lama.

g. Model

Model menggambarkan seberapa jauh suatu produk tampak dan berkenan bagi konsumen. Model memberi keunggulan ciri kekhususan produk yang sulit untuk ditiru. Sebagai contoh, banyak pembeli mobil yang membayar lebih untuk mobil jaguar karena penampilannya yang luar biasa walaupun jaguar sendiri tidak begitu baik dari segi ketahanan uji (reliability)

Penelitian tentang Desain telah banyak dikaji oleh penelitian sebelumnya seperti penelitian yang dikembangkan oleh (M \& Ali, 2017), (Ali, 2019a), (Setyadi \& Ali, 2017), (Agussalim \& Ali, 2017), (Cheong \& Jang, 2008), (Kazmi \& Mehmood, 2016), (Yu et al., 2013), (Rosyid et al., 2013), (Kazmi \& Mehmood, 2016)(Kazmi \& Mehmood, 2016)(Kazmi \& Mehmood, 2016)(Kazmi \& Mehmood, 2016)(Sivaram et al., 2019), (Chovanová et al., 2015), (Durrani et al., 2015), (Foster, 2017), (Suhaily, 2017).

\section{Endorse}

Menurut (Shimp 2015) Endorser adalah menggunakan artis sebagai bintang iklan di mediamedia, mulai dari media cetak, media sosial, maupun media telivisi.. Dan endorse digunakan karena berbagai atribut yang ada dirinya yang merupakan cara ampuh untuk menarik minat konsumen sehingga banyaknya para produsen menggunakan cara ini untuk meningkatankan penjualan pada produk mereka. Sedangkan menurut (Leslie 2019) mendefinisi celebrity endorser merupakan bagian penting dari suatu kampanye pemasaran produk. Harapan dari penggunaan celebrity endorsement adalah image atau kualitas selebriti akan berpindah terhadap produk dan merangsang penjualan. Menggunakan selebriti sebagai endorser memiliki keuntungan yaitu dari segi publisitas dan kemudahan mendapatkan perhatian dari calon konsumen.

Biasanya selebriti memiliki penggemar yang dapat menerjemahkan atau mengubah bahkan menciptakan target pasar. Mereka dapat memberikan informasi yang berharga ketika aspek selebriti cocok dengan produk, baik, disukai dan sikap mereka atau khusus yang mengarah ke identifikasi dan persuasi konsumen yang kemungkinan membangun hubungan baik antara produk dengan dampak selebriti (Belch 2020).

Endorse merupakan seseorang yang mendukung opini atau tindakan untuk mendukung suatu produk. Sehingga produsen melakukan seleksi dalam hal karakteristik harus diluruskan dengan efek komunikasi yang ingin ditimbulkan atau dimunculkan pada saat perikalanan. Menurut (Young dan Pinsky 2018) penggunaan endorse sebagai pendukung iklan dinilai sangat baik karena bidaya masyarakat tentang keingintahuan mereka tentang akan selebrity idolanya. 
Dari penjelasan diatas maka dapat disimpulkan bahwa pengirim pesan dengan menggunakan sumber yang terkredibilitas tinggi dapat berpengaruh terhadap perubahan sikap oleh konsumen yang tentunya juga diharapkan oleh produsen yang bertujuan adanya kedasaran konsumen dan memiliki dampak pada pengaruh keputusan pembelian. Penggunaan selebriti sendiri biasanya menimbulkan kesan bahwa konsumen yang selektif dalam memilih dan meningkatkan status dengan memiliki apa yang digunakan oleh selebriti. Celebrity endorser dukungan selebriti baik berupa pengenalan maupun pengesahan terhadap suatu produk yang dapat menarik perhatian audience ataupun konsumen. Menurut (Kanuk 2020:287), daya tarik selebriti digunakan dengan sangat efektif oleh para pemasang iklan untuk berkomunikasi dengan pasar-pasar mereka. Para selebriti dapat menjadi kekuatan yang berpengaruh dalam menimbulkan minat atau tindakan yang berhubungan dengan pembelian atau penggunaan barang-barang dan jasajasa yang dipilih. Menurut (Shimp 2016) terdapat atribut dasar yang berpengaruh terhadap efektifitas endorse yaitu:

\section{Attractiveness}

Daya tarik bukan hanya berarti daya tarik fisik, meskipun daya tarik bisa menjadi atribut yang sangat penting tetapi meliputi sejumlah karakteristik yang dapat dilihat khalayak dalam diri endorser/pendukung, kecerdasan, sifat-sifat kepribadian, gaya hidup, keatletisan postur tubuh, dan sebagainya. Konsep umum daya Tarik terdiri dari 3 yaitu:

a. Similiraty, merupakan persepsi khalayak berkenaan dengan kesamaan yang dimiliki dengan endorser, kemiripan ini dapat berupa gaya hidup, kepribadian, masalah yang dihadapi sebagaimana yang ditampilkan pada iklan, dan sebagainya

b. Familiarity, adalah pengenalan terhadap narasumber melalui exposure. Sebagai contoh, penggunaan celebrity endorser dinilai berdasarkan tingkat keseringan tampil di publik.

c. Liking, adalah kesukaan audiens terhadap narasumber karena penampilan fisik yang menarik, perilaku yang baik, atau karakter personal lainnya.

\section{Credibility}

Kredibilitas mengacu pada kecenderungan untuk percaya kepada seseorang. Kredibilitas memiliki dua sifat penting yaitu:

a. Expertise, $m$ mengacu pada pengetahuan, pengalaman, atau keterampilan yang dimiliki endorser berkaitan dengan produk yang diiklankan.

b. Trustworthiness, mengacu kepada kejujuran, integritas, dapat dipercayainya seorang sumber.

\section{Indikator Endorse}

Beberapa indikator penting terkait endorse menurut (Saaksjarvi 2019) yaitu:

a. Kredibilitas (credibility), mengacu pada kecenderungan untuk percaya atau mempercayai endorser, terkait keahliannya dan kepercayaan terhadapnya. 
b. Daya tarik (attractiveness) terdiri dari tiga dimensi yang terkait kesamaan, keakraban, dan disukai. Daya tarik tidak hanya fisik, tapi juga meliputi sejumlah karakteristik yang menjadi kelebihan endorser, seperti keterampilan intelektual, sifat kepribadian, karakteristik gaya hidup, kecakapan dan sebagainya.

c. Kekuatan (power), kharisma yang dipancarkan oleh narasumber sehingga dapat mempengaruhi pemikiran, sikap, atau tingkah laku konsumen karena pernyataan atau pesan endorser tersebut.

Penelitian tentang Endorse telah banyak dikaji oleh penelitian sebelumnya seperti penelitian yang dikembangkan oleh (M \& Ali, 2017), (Ali, 2019a), (Setyadi \& Ali, 2017), (Agussalim \& Ali, 2017), (Cheong \& Jang, 2008), (Kazmi \& Mehmood, 2016), (Yu et al., 2013), (Rosyid et al., 2013), (Kazmi \& Mehmood, 2016)(Kazmi \& Mehmood, 2016)(Kazmi \& Mehmood, 2016)(Kazmi \& Mehmood, 2016)(Sivaram et al., 2019), (Chovanová et al., 2015), (Durrani et al., 2015), (Foster, 2017), (Suhaily, 2017).

\section{METODE PENULISAN}

Metode penulisan artikel ilmiah ini adalah dengan metode kualitatif dan studi literature atau Library Research. Mengkaji Buku-buku literature sesuai dengan teori yang di bahas khusunya di lingkup Manajemen Pemasaran. Disamping itu menganalisis artikel-artikel ilmiah yang bereputasi dan juga artikel ilmiah dari jurnal yang belum bereputasi. Semua artikel ilmiah yang di citasi bersumber dari Mendeley dan Scholar Google.

Dalam penelitian kualitatif, kajian pustaka harus digunakan secara konsisten dengan asumsi-asumsi metodologis. Artinya harus digunakan secara induktif sehingga tidak mengarahkan pertanyaan-pertanyaan yang diajukan oleh peneliti. Salah satu alasan utama untuk melakukan penelitian kualitatif yaitu bahwa penelitian tersebut bersifat eksploratif, (Ali \& Limakrisna, 2013).

Selanjutnya dibahas secara mendalam pada bagian yang berjudul" Pustaka Terkait" (Related Literature) atau Kajian pustaka( "Review of Literature"), sebagai dasar perumusan hipotesis dan selanjutnya akan menjadi dasar untuk melakukan perbandingan dengan hasil atau temuan-temuan yang terungkap dalam penelitian, (Ali \& Limakrisna, 2013).

\section{PEMBAHASAN}

\section{Pengaruh kualitas produk terhadap nilai pelanggan}

Menurut (Philip Kotler 2015) Kualitas produk merupakan ciri dan karakteristik suatu barang atau jasa yang berpengaruh pada kemampuannya untuk memuaskan kebutuhan yang dinyatakan maupun tersirat. Kualitas merupakan hal yang penting bagi para produsen yang harus diusahakan agar produk yang dihasilkan dapat bersaing di pangsa pasar, ini dikarenakan pada saat ini konsumen lebih teliti memilih dalam mendapatkan suatu produk yang memberikan kepuasan yang diinginkan.

(Rangkuti 2015:13) mendefinisikan nilai sebagai pengkajian secara menyeluruh manfaat dari suatu produk, didasarkan persepsi pelanggan atas apa yang telah diterima oleh 
pelanggan dan yang telah diberikan oleh produk tersebut. Nilai dapat mencerminkan sejumlah manfaat, baik yang berwujud maupun yang tidak berwujud.

Kualitas produk yang kuat menandakan bahwa konsumen akan menambah nilai pelanggan terhadap produk yang dibelinya (Agussalim \& Ali, 2017). Kualitas produk secara signifikan mempengaruhi nilai pelanggan (Cheong \& Jang, 2018).

\section{Pengaruh kualitas produk terhadap Keputusan pembelian}

Apabila dalam situasi pemasaran yang semakin ketat persaingannya, peranan kualitas produk akan semakin besar dalam perkembangan perusahaan. Selain itu, konsumen akan menyukai produk yang menawarkan kualitas, kinerja, dan pelengkap inovatif yang terbaik. (Lupiyoadi dan Hamdani 2019:131). Menurut (Philip Kotler 2015) Kualitas produk merupakan ciri dan karakteristik suatu barang atau jasa yang berpengaruh pada kemampuannya untuk memuaskan kebutuhan yang dinyatakan maupun tersirat. Kualitas merupakan hal yang penting bagi para produsen yang harus diusahakan agar produk yang dihasilkan dapat bersaing di pangsa pasar,

(Yu et al., 2013) menemukan bahwa kualitas produk memiliki dampak positif pada keputusan pembelian. Faktor kualitas produk, desain produk dan nilai pelanggan dapat mempengaruhi secara positif perilaku pembelian suatu produk (Ali, 2019a). (Rosyid et al., 2013) kualitas produk berpengaruh positif terhadap keputusan pembelian. (Suhaily, 2017) kualitas produk berpengaruh positif dan signifikan terhadap keputusan pembelian.

\section{Pengaruh Desain Produk terhadap Nilai pelanggan}

Menurut (Kotler dan Keller 2020) menyatakan desain produk adalah segala fitur yang dimiliki oleh produk yang dapat mempengaruhi keberadaannya. Aspek desain dalam kegiatan pemasaran merupakan salah satu hal yang membuat daya tarik terhadap suatu produk, desain akan menjadi cara yang paling ampuh untuk menambah manfaat produk kepada pelanggan. (Anandya 2017) menyatakan bahwa desain produk menjadi pembeda produk suatu merek dengan merek lainnya yang menciptakan ciri khas bagi suatu merek. Menurut (Kotler dan Armstrong 2019b) desain yang baik mempertimbangkan bentuk eksternal tetapi juga menciptakan produk yang mudah, aman, tidak mahal untuk penggunaan dan layanan, mudah dan ekonomis untuk di produksi dan didistribusikan Menurut (Pero et al 2018) mengemukakan bahwa desain produk adalah totalitas dari fitur-fitur itu yang mempengaruhi penampilan fisik dan fungsi produk dalam hal kebutuhan konsumen.

(Amanah et al., 2017) dengan hasil penelitian menunjukkan bahwa desain produk berpengaruh positif dan secara signifikan dapat memengaruhi nilai pelanggan. Adapun hasil (Yen, 2019) menemukan desain produk memiliki pengaruh yang besar terhadap nilai pelanggan

\section{Pengaruh Desain Produk terhadap Keputusan Pembelian}

Kotler mengatakan "desain merupakan totalitas keistimewaan yang mempengaruhi penampilan dan fungsi suatu produk dari segi kebutuhan konsumen" (Kotler dan Keller 2017). Produk hasil desain produk kerajinan umumnya lebih menitikberatkan pada nilai-nilai 
keunikan (uniqueness), estetika (keindahan), seni (art), adiluhung, berharkat tinggi, khusus, khas, dan kehalusan rasa sebagai unsur dasar. Sementara dalam pemenuhan fungsinya lebuh menekankan pada pemenuhan fungsi pakai yang lebih bersifat fisik (fisiologis), misalnya: benda-benda pakai, perhiasan, furnitur, atau pun sandang (Palgunadi 2018).

Keputusan pembelian merupakan suatu proses pengambilan keputusan akan pembelian yang mencakup penentuan apa yang akan dibeli atau tidak melakukan pembelian dan keputusan itu diperoleh dari kegiatan-kegiatan sebelumnya ( Assauri 2016) Kotler mengatakan yang dimaksud dengan keputusan pembelian adalah "suatu proses penyelesaian masalah yang terdiri dari menganalisa atau pengenalan kebutuhan dan keinginan, pencarian informasi, penilaian sumber-sumber seleksi terhadap alternatif pembelian, keputusan pembelian, dan perilaku setelah pembelian" (Kotler dan Keller 2017).

Penelitian oleh (Gan \& Wang, 2017) desain produk berpengaruh positif signifikan terhadap keputusan pembelian. Semakin bagus desain sebuah produk maka akan meningkatkan keputusan pembelian (Yunita \& Ali, 2017). (Rosyid et al., 2013) desain produk berpengaruh positif terhadap keputusan pembelian, perusahaan harus fokus dalam menggembangkan produk yang mereka jualbaik dalam segi kualitas maupun desain produk supaya menarih hati konsumen. Sama halnya dengan (Rödiger et al., 2016) desain produk yang bagus dapat mempengaruhi konsumen untuk membeli. (Amanah et al., 2017) dengan hasil penelitian menunjukkan bahwa desain produk dan kualitas produk berpengaruh positif dan secara signifikan dapat memengaruhi keputusan pembelian (Konuk, 2018; (Ferdinand, 2014))

\section{Pengaruh Endorse terhadap Nilai Pelanggan}

Menurut (Shimp 2015) Endorser adalah menggunakan artis sebagai bintang iklan di media-media, mulai dari media cetak, media sosial, maupun media telivisi.. Dan endorse digunakan karena berbagai atribut yang ada dirinya yang merupakan cara ampuh untuk menarik minat konsumen sehingga banyaknya para produsen menggunakan cara ini untuk meningkatankan penjualan pada produk mereka. Sedangkan menurut (Leslie 2019) mendefinisi celebrity endorser merupakan bagian penting dari suatu kampanye pemasaran produk. Harapan dari penggunaan celebrity endorsement adalah image atau kualitas selebriti akan berpindah terhadap produk dan merangsang penjualan. Menggunakan selebriti sebagai endorser memiliki keuntungan yaitu dari segi publisitas dan kemudahan mendapatkan perhatian dari calon konsumen. Menurut (Kotler dalam Hurriyati 2017) nilai pelanggan adalah sekumpulan manfaat yang diharapkan oleh pelanggan dari produk atau jasa tertentu dan biaya pelanggan total adalah sekumpulan biaya yang diharapkan oleh konsumen yang dikeluarkan untuk mengevaluasi, mendapatkan, menggunakan dan membuang produk atau jasa. Dan hubungan yang diinginkan adalah hubungan yang bersifat jangka panjang, sebab usaha dan biaya yang dikeluarkan oleh perusahaan diyakini akan jauh lebih besar apabila harus menarik pelanggan baru atau pelanggan yang sudah meninggalkan perusahaan, daripada mempertahankannya.

\section{Pengaruh Endorse terhadap Keputusan Pembelian}


Menurut (Shimp 2015) Endorser adalah menggunakan artis sebagai bintang iklan di mediamedia, mulai dari media cetak, media sosial, maupun media telivisi.. Dan endorse digunakan karena berbagai atribut yang ada dirinya yang merupakan cara ampuh untuk menarik minat konsumen sehingga banyaknya para produsen menggunakan cara ini untuk meningkatankan penjualan pada produk mereka. Sedangkan menurut (Leslie 2019) mendefinisi celebrity endorser merupakan bagian penting dari suatu kampanye pemasaran produk. Harapan dari penggunaan celebrity endorsement adalah image atau kualitas selebriti akan berpindah terhadap produk dan merangsang penjualan. Menggunakan selebriti sebagai endorser memiliki keuntungan yaitu dari segi publisitas dan kemudahan mendapatkan perhatian dari calon konsumen.

Keputusan pembelian merupakan sikap dalam membeli atau menggunakan suatu produk yang menurut konsumen memberikan kepuasan ataupun resiko yang mungkin ada terjadi. Menurut (Schiffman dan Kanuk 2015) keputusan pembelian adalah pemilihan dari dua atau lebih alternatif pilihan keputusan pembelian, artinya bahwa seseorang dapat membuat keputusan, harus tersedia beberapa alternatif pilihan. Keputusan untuk membeli dapat mengarah pada bagaimana proses dalam pengambilan keputusan tersebut itu dilakukan.

Menurut (Kotler dan Armstrong 2017:180) keputusan pembelian adalah keputusan pembeli tentang merek mana yang dibeli. Proses pengambilan keputusan yang rumit sering melibatkan beberapa keputusan. Keputusan ini melibatkan pilihan antara dua atau lebih alternatif. Keputusan pembelian konsumen adalah tahap dimana konsumen juga mungkin membentuk niat untuk membeli produk yang paling disukai, dimana keputusan konsumen untuk memodifikasi, menunda, atau menghindar sangat dipengaruhi resiko yang dirasakan.

\section{Pengaruh Nilai Pelanggan terhadap Keputusan pembelian}

Menurut (Kotler dalam Hurriyati 2017) nilai pelanggan adalah sekumpulan manfaat yang diharapkan oleh pelanggan dari produk atau jasa tertentu dan biaya pelanggan total adalah sekumpulan biaya yang diharapkan oleh konsumen yang dikeluarkan untuk mengevaluasi, mendapatkan, menggunakan dan membuang produk atau jasa. Dan hubungan yang diinginkan adalah hubungan yang bersifat jangka panjang, sebab usaha dan biaya yang dikeluarkan oleh perusahaan diyakini akan jauh lebih besar apabila harus menarik pelanggan baru atau pelanggan yang sudah meninggalkan perusahaan, daripada mempertahankannya.

Menurut (Zeithmal dan Biner 2016) menyampaikan bahwa terdapat beberapa cara yang tepat untuk menetapkan harga produk berdasarkan defenisi nilai untuk pelanggan, yaitu : value is low price, value is everything I want in a service,value is quality I get for the price I pay, value is all that I get from all that I give.

Nilai pelanggan akan menciptakan kepercayaan yang baik pada penjual dan akan meningkatkan konsumen dalam perilaku pembelian (Larasetiati \& Ali, 2019). Nilai pelanggan memiliki efek langsung dan signifikan terhadap niat beli (Firmansyah \& Ali, 2019) (Zhao et al., 2019) dan nilai pelanggan merupakan faktor penting dalam meningkatkan minat belanja online. Mosunmola et al. (2019) juga menemukan adanya pengaruh antara nilai pelanggan dengan minat beli. (Jeaheng et al., 2020) nilai pelanggan berpengaruh positif dan signifikan 
terhadap keputusan pembelian. (Damghanian et al., 2016) nilai pelanggan yang tinggi dapat mengurangi risiko yang di persepsikan konsumen sehingga dapat berdampak pada keputusan pembelian.

\section{Prariset}

\section{Hubungan tidak lansung}

\section{Pengaruh kualitas produk terhadap Keputusan pembelian melalui Nilai pelanggan}

Apabila dalam situasi pemasaran yang semakin ketat persaingannya, peranan kualitas produk akan semakin besar dalam perkembangan perusahaan. Selain itu, konsumen akan menyukai produk yang menawarkan kualitas, kinerja, dan pelengkap inovatif yang terbaik. (Lupiyoadi dan Hamdani 2019:131). Menurut (Philip Kotler 2015) Kualitas produk merupakan ciri dan karakteristik suatu barang atau jasa yang berpengaruh pada kemampuannya untuk memuaskan kebutuhan yang dinyatakan maupun tersirat. Kualitas merupakan hal yang penting bagi para produsen yang harus diusahakan agar produk yang dihasilkan dapat bersaing di pangsa pasar,

Menurut (Kotler dalam Hurriyati 2017) nilai pelanggan adalah sekumpulan manfaat yang diharapkan oleh pelanggan dari produk atau jasa tertentu dan biaya pelanggan total adalah sekumpulan biaya yang diharapkan oleh konsumen yang dikeluarkan untuk mengevaluasi, mendapatkan, menggunakan dan membuang produk atau jasa. Dan hubungan yang diinginkan adalah hubungan yang bersifat jangka panjang, sebab usaha dan biaya yang dikeluarkan oleh perusahaan diyakini akan jauh lebih besar apabila harus menarik pelanggan baru atau pelanggan yang sudah meninggalkan perusahaan, daripada mempertahankannya.

(Yu et al., 2013) menemukan bahwa kualitas produk memiliki dampak positif pada keputusan pembelian. Faktor kualitas produk, desain produk dan nilai pelanggan dapat mempengaruhi secara positif perilaku pembelian suatu produk (Ali, 2019a). (Rosyid et al., 2013) kualitas produk berpengaruh positif terhadap keputusan pembelian. (Suhaily, 2017) kualitas produk berpengaruh positif dan signifikan terhadap keputusan pembelian.

\section{Pengaruh desain produk terhadap Keputusan pembelian melalui Nilai pelanggan}

Kotler mengatakan "desain merupakan totalitas keistimewaan yang mempengaruhi penampilan dan fungsi suatu produk dari segi kebutuhan konsumen" (Kotler dan Keller 2017). Produk hasil desain produk kerajinan umumnya lebih menitik beratkan pada nilai-nilai keunikan (uniqueness), estetika (keindahan), seni (art), berharkat tinggi, khusus, khas, dan kehalusan rasa sebagai unsur dasar. Sementara dalam pemenuhan fungsinya lebuh menekankan pada pemenuhan fungsi pakai yang lebih bersifat fisik (fisiologis), misalnya: benda-benda pakai, perhiasan, furnitur, atau pun sandang (Palgunadi 2018).

Menurut (Kotler dalam Hurriyati 2017) nilai pelanggan adalah sekumpulan manfaat yang diharapkan oleh pelanggan dari produk atau jasa tertentu dan biaya pelanggan total adalah sekumpulan biaya yang diharapkan oleh konsumen yang dikeluarkan untuk mengevaluasi, mendapatkan, menggunakan dan membuang produk atau jasa. Dan hubungan yang diinginkan adalah hubungan yang bersifat jangka panjang, sebab usaha dan biaya yang dikeluarkan oleh 
perusahaan diyakini akan jauh lebih besar apabila harus menarik pelanggan baru atau pelanggan yang sudah meninggalkan perusahaan, daripada mempertahankannya.

Keputusan pembelian merupakan suatu proses pengambilan keputusan akan pembelian yang mencakup penentuan apa yang akan dibeli atau tidak melakukan pembelian dan keputusan itu diperoleh dari kegiatan-kegiatan sebelumnya ( Assauri 2016) Kotler mengatakan yang dimaksud dengan keputusan pembelian adalah "suatu proses penyelesaian masalah yang terdiri dari menganalisa atau pengenalan kebutuhan dan keinginan, pencarian informasi, penilaian sumber-sumber seleksi terhadap alternatif pembelian, keputusan pembelian, dan perilaku setelah pembelian" (Kotler dan Keller 2017).

\section{Pengaruh endorse terhadap Keputusan pembelian melalui Nilai pelanggan}

Menurut (Shimp 2015) Endorser adalah menggunakan artis sebagai bintang iklan di mediamedia, mulai dari media cetak, media sosial, maupun media telivisi. Dan endorse digunakan karena berbagai atribut yang ada dirinya yang merupakan cara ampuh untuk menarik minat konsumen sehingga banyaknya para produsen menggunakan cara ini untuk meningkatankan penjualan pada produk mereka. Sedangkan menurut (Leslie 2019) mendefinisi celebrity endorser merupakan bagian penting dari suatu kampanye pemasaran produk. Harapan dari penggunaan celebrity endorsement adalah image atau kualitas selebriti akan berpindah terhadap produk dan merangsang penjualan. Menggunakan selebriti sebagai endorser memiliki keuntungan yaitu dari segi publisitas dan kemudahan mendapatkan perhatian dari calon konsumen.

Menurut (Kotler dalam Hurriyati 2017) nilai pelanggan adalah sekumpulan manfaat yang diharapkan oleh pelanggan dari produk atau jasa tertentu dan biaya pelanggan total adalah sekumpulan biaya yang diharapkan oleh konsumen yang dikeluarkan untuk mengevaluasi, mendapatkan, menggunakan dan membuang produk atau jasa. Dan hubungan yang diinginkan adalah hubungan yang bersifat jangka panjang, sebab usaha dan biaya yang dikeluarkan oleh perusahaan diyakini akan jauh lebih besar apabila harus menarik pelanggan baru atau pelanggan yang sudah meninggalkan perusahaan, daripada mempertahankannya.

Keputusan pembelian merupakan suatu proses pengambilan keputusan akan pembelian yang mencakup penentuan apa yang akan dibeli atau tidak melakukan pembelian dan keputusan itu diperoleh dari kegiatan-kegiatan sebelumnya ( Assauri 2016) Kotler mengatakan yang dimaksud dengan keputusan pembelian adalah "suatu proses penyelesaian masalah yang terdiri dari menganalisa atau pengenalan kebutuhan dan keinginan, pencarian informasi, penilaian sumber-sumber seleksi terhadap alternatif pembelian, keputusan pembelian, dan perilaku setelah pembelian" (Kotler dan Keller 2017).

\section{Conceptual Framework}

Berdasarkan rumusan masalah penulisan artikel ini dan kajian studi literature review baik dari buku dan artikel yang relevan, maka di perolah rerangka artikel ini seperti di bawah ini. 


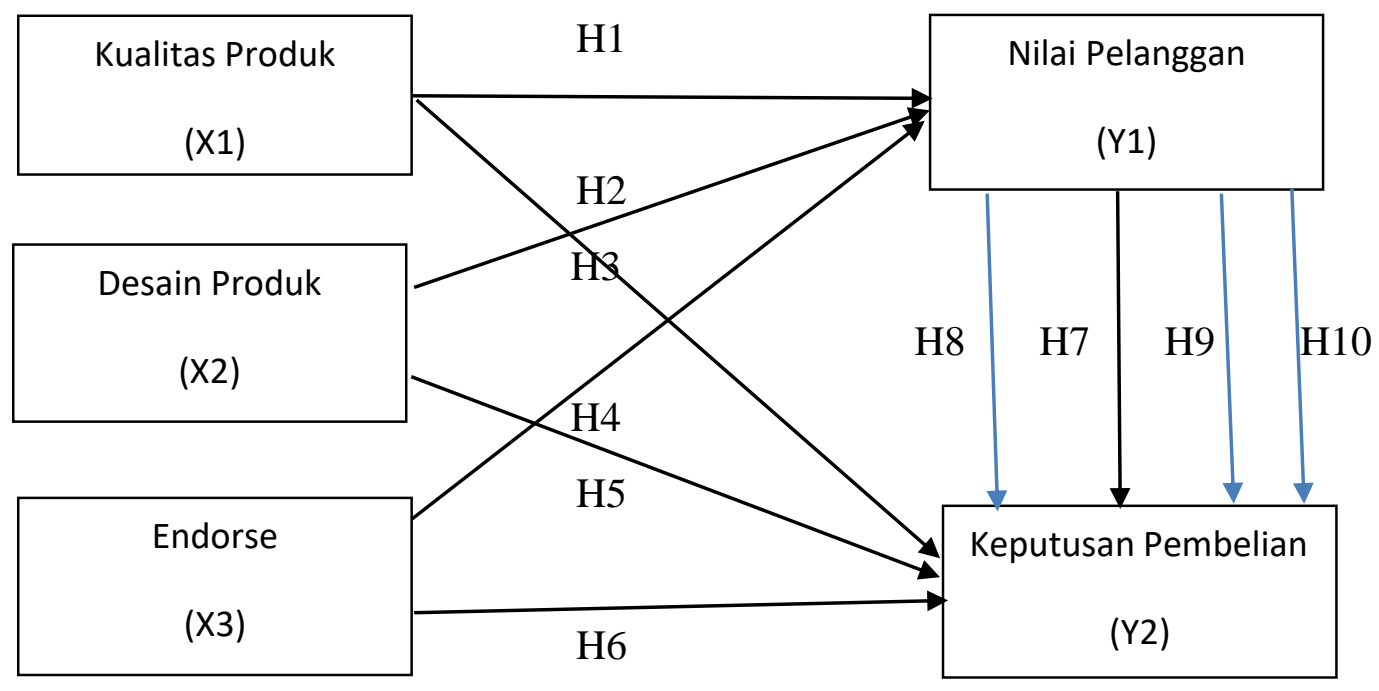

Gambar 1

Conceptual Framework

Kualitas produk,desain produk dan endorse memiliki hubungan dan berpengaruh terhadap nilai pelanggan dan keputusan pembelian baik secara langsung maupun tidak langsung.

Selain dari variabel Kualitas produk,desain produk dan endorse yang mempengaruh kepercayaan dan keputusan pembelian masih banyak variabel lain yang mempengaruhinya, di antaranya adalah variabel:

1) Promotion (x3): (Ali, Evi, et al., 2018), (Prihartono \& Ali, 2020), (Richardo et al., 2020), (Mappesona et al., 2020), (Sulistiorini \& Ali, 2017), (Hairiyah \& Ali, 2017), (Ali, Narulita, et al., 2018), and (Brata et al., 2017).

2) Kepercayaan (x4) : (M \& Ali, 2017),(Limakrisna \& Ali, 2016), (Yunita \& Ali, 2017), (Yunita \& Ali, 2017), (Ali \& Mappesona, 2016), (Ali, Evi, et al., 2018), (Sitio \& Ali, 2019), and (Anggita \& Ali, 2017).

3) Harga (x5): (M \& Ali, 2017), (Ali, Narulita, et al., 2018), (M \& Ali, 2017), (Ali, Evi, et al., 2018), (Prihartono \& Ali, 2020), (Riyanto et al., 2017), (Maisah \& Ali, 2020), (Brata et al., 2017), (Thanh Nguyen et al., 2019), (Ali, 2019), and (Anggita \& Ali, 2017).

\section{KESIMPULAN DAN SARAN}

\section{Kesimpulan}

Berdasarkan rumusan masalah dan conceptual framework maka dapat disimpulkan sebagai hipotesis Berdasarkan rumusan artikel, hasil dan pembahasan, maka dapat di di rumuskan hipotesis untuk riset selanjutnya:

1. Kualitas produk berpengaruh terhadap nilai pelanggan

2. Kualitas produk berpengaruh terhadap keputusan pembelian 
3. Desain produk berpengaruh terhadap nilai pelanggan

4. Desain produk berpengaruh terhadap keputusan pembelian

5. Endorse berpengaruh terhadap nilai pelanggan

6. Endorse berpengaruh terhadap keputusan pembelian

7. Nilai pelanggan berpengaruh terhadap keputusan pembelian

8. Kualitas produk berpengaruh terhadap keputusan pembelian melalui nilai pelanggan

9. Desain produk berpengaruh terhadap keputusan pembelian melalui nilai pelanggan

10. Endorse berpengaruh terhadap keputusan pembelian melalui nilai pelanggan

\section{Saran}

Bersdasarkan Kesimpulan di atas, maka saran pada artikel ini adalah bahwa masih banyak faktor lain yang mempengaruhi nilai pelanggan dan keputusan pembelian, selain dari kualitas produk dan desain produk pada semua tipe dan level organisasi atau perusahaan, oleh karena itu masih di perlukan kajian yang lebih lanjut untuk mencari faktor-faktor lain apa saja yang dapat memepengaruhi nilai pelanggan dan keputusan pembelian selain yang di teliti pada arikel ini.

\section{Daftar Pustaka}

Agussalim, M., Limakrisna, N., \& Ali, H. (2017b). Mutual Funds Performance: Conventional and Sharia Product. International Journal of Economics and Financial Issues.

Al-ekam, J. M. E. (2016). The mediating effect of brand trust on the influence of communication, price, and product quality on consumer purchase behaviour in a lessdeveloped country. Malaysian Management Journal, 20(December), 87-97.

Ali, H. (2019a). Building Repurchase Intention and Purchase Decision: Brand Awareness and Brand Loyalty Analysis (Case Study Private Label Product in Alfamidi Tangerang). Saudi Journal of Humanities and Social Sciences, 04(09), 623-634. https://doi.org/10.36348/sjhss.2019.v04i09.009

Ali, H. (2019b). Purchase Decision and Repurchase Models: Product Quality and Process Analysis (Case Study of House Ownership Credit Financing in Permata Sharia Bank Jakarta). Scholars Bulletin. https://doi.org/10.36348/sb.2019.v05i09.006

Ali, H., Evi, N., \& Nurmahdi, A. (2018). The Influence of Service Quality , Brand Image and Promotion on Purchase Decision at MCU Eka Hospital. Business and Management Studies. https://doi.org/10.21276/sjbms.2018.3.1.12

Ali, H., \& Mappesona, H. (2016). Build brand image: Analysis Service Quality and Product Quality (case study at Giant Citra Raya). International Journal of Economic Research.

Ali, H., Narulita, E., \& Nurmahdi, A. (2018). Saudi Journal of Business and Management Studies ( SJBMS ) The Influence of Service Quality, Brand Image and Promotion on Purchase Decision at MCU Eka Hospital. Business and Management Studies. https://doi.org/10.21276/sjbms.2018.3.1.12

Amanah, D., Hurriyati, R., Gaffar, V., Wibowo, L. A., \& Harahap, D. A. (2017). Which is More Influential in Online Purchasing Decisions : Price or Trust? Which is More Influential in Online Purchasing Decisions : Price or Trust? November. 
https://doi.org/10.5220/0007090107980803

Anggita, R., \& Ali, H. (2017). The Influence of Product Quality, Service Quality and Price to Purchase Decision of SGM Bunda Milk (Study on PT. Sarihusada Generasi Mahardika Region Jakarta, South Tangerang District). Scholars Bulletin. https://doi.org/10.21276/sb

Brata, B. H., Husani, S., \& Ali, H. (2017). The Importance of Quality Products, Price, Promotion, and Location to Product Purcese Decision on Nitchi At PT. Jaya Swarasa Agung in Central Jakarta. Saudi Journal of Business and Management Studies. https://doi.org/10.21276/sjbms

Cheong \&Jang. (2008). Determinants of Internet Usage in Ghanaian Hotels : The Case of the Greater Accra Region ( GAR ) Determinants of Internet Usage in Ghanaian Hotels : The Case of the Greater Accra Region ( GAR ). Journal of Hospitality \& Leisure Marketing, 15(3), 37-41. https://doi.org/10.1300/J150v15n03

Chovanová, H. H., Korshunov, A. I., \& Babčanová, D. (2015). Impact of Brand on Consumer Behavior. Procedia Economics and Finance, 34(9), 615-621. https://doi.org/10.1016/s2212-5671(15)01676-7

Damghanian, H., Zarei, A., \& Siahsarani Kojuri, M. A. (2016). Impact of Perceived Security on Trust, Perceived Risk, and Acceptance of Online Banking in Iran. Journal of Internet Commerce, 15(3), 214-238. https://doi.org/10.1080/15332861.2016.1191052

Djatmiko, T., \& Pradana, R. (2016). Brand Image and Product Price; Its Impact for Samsung Smartphone Purchasing Decision. Procedia - Social and Behavioral Sciences, 219, 221 227. https://doi.org/10.1016/j.sbspro.2016.05.009

Dudu, O., \& Agwu, M. (2014). A Review of The Effect of Pricing Strategies on The Purchase of Consumer Goods. International Journal of Research in Management, Science \& Technology, 2(2), 88-102.

Ferdinand, T. dan. (2014). Analyzing the Influence of Price and Product Quality on Buying Decision. Jurnal EMBA, 2(3), 1255-1263.

Firmansyah, N., \& Ali, H. (2019). Consumer Trust Model : The Impact of Satisfaction and EService Quality toward Repurchase Intention in E-Commerce. 6256, 552-559. https://doi.org/10.21276/sjhss.2019.4.8.4

Foster, B. (2017). Impact of Brand Image on Purchasing Decision on Mineral Water Product "Amidis" (Case Study on Bintang Trading Company). American Research Journal of Humanities and Social Sciences, 2(1), 1-11. https://doi.org/10.21694/2378-7031.16023

Gan, C., \& Wang, W. (2017). The influence of perceived value on purchase intention in social commerce context. Internet Research, 27(4), 772-785.

https://doi.org/10.1108/IntR-06-2016-0164

Hairiyah, S., \& Ali, H. (2017). Customer Decision Analysis in Taking Multipurpose Loan : Promotions, Locations and Credit Procedures ( A Case of the Bank " PQR Jakarta "). Saudi Journal of Business and Management Studies. https://doi.org/10.21276/sjbms.2017.2.3.6

Jeaheng, Y., Al-Ansi, A., \& Han, H. (2020). Impacts of Halal-friendly services, facilities, and food and Beverages on Muslim travelers' perceptions of service quality attributes, perceived price, satisfaction, trust, and loyalty. Journal of Hospitality Marketing and Management, 29(7), 787-811. https://doi.org/10.1080/19368623.2020.1715317 
Kazmi, A., \& Mehmood, Q. S. (2016). The effect of electronic word of mouth communication and brand image on purchase intention: A case of consumer electronics in Haripur, Pakistan. Management Science Letters, 6, 409-508. https://doi.org/10.5267/j.msl.2016.5.003

Kim, E. J., Kim, S. H., \& Lee, Y. K. (2019). The effects of brand hearsay on brand trust and brand attitudes. Journal of Hospitality Marketing and Management, 28(7), 765-784. https://doi.org/10.1080/19368623.2019.1567431

Konuk, F. A. (2018). Price fairness, satisfaction, and trust as antecedents of purchase intentions towards organic food. Journal of Consumer Behaviour, 17(2), 141-148. https://doi.org/10.1002/cb.1697

Larasetiati, M., \& Ali, H. (2019). Model of Consumer Trust: Analysis of Perceived Usefulness and toward Repurchase Intention in Online Travel Agent. Journal of Economics and Finance, 3(8), 350-357. https://doi.org/10.21276/sjef.2019.3.8.5

Limakrisna, N., \& Ali, H. (2016). Model of Customer Satisfaction: Empirical Study At Fast Food Restaurants in Bandung. International Journal of Business and Commerce.

M, A., \& Ali, H. (2017). MODEL KEPUASAN PELANGGAN: ANALISIS KUALITAS PRODUK DAN KUALITAS LAYANAN TERHADAP CITRA MEREK PADA GIANT CITRA RAYA JAKARTA. Jurnal Manajemen. https://doi.org/10.24912/jm.v21i3.254

Maisah, \& Ali, H. (2020). Entrepreneurship culture development process: Implementation of Islamic education values in the Batik Jambi (case study in Seberang Jambi community). Talent Development and Excellence.

Mappesona, H., Ikhsani, K., \& Ali, H. (2020). Customer purchase decision model, supply chain management and customer satisfaction: Product quality and promotion analysis. International Journal of Supply Chain Management.

Mosunmola, A., Adegbuyi, O., Kehinde, O., Agboola, M., \& Olokundun, M. (2019). Percieved value dimensions on online shopping intention: The role of trust and culture. Academy of Strategic Management Journal, 18(1), 1-20.

Novansa, H., \& Ali, H. (1926). Purchase Decision Model: Analysis of Brand Image, Brand Awareness and Price (Case Study SMECO Indonesia SME products). Saudi Journal of Humanities and Social Sciences. https://doi.org/10.21276/sjhss

Pappas, I. O. (2018). User experience in personalized online shopping: a fuzzy-set analysis. European Journal of Marketing, 52(7-8), 1679-1703. https://doi.org/10.1108/EJM-102017-0707

Prihartono, \& Ali, H. (2020). The promises ethics and marketing concept strategy as a competitive advantage on private higher education (A survey on perception of product attributes and promotion mix in Indonesia). Talent Development and Excellence.

Richardo, Hussin, M., Bin Norman, M. H., \& Ali, H. (2020). A student loyalty model: Promotion, products, and registration decision analysis-Case study of griya english fun learning at the tutoring institute in wonosobo central Java. International Journal of Innovation, Creativity and Change.

Riyanto, S., Adila, L., \& Ali, H. (2017). The Effect of Incentives And Job Enthusiasm To Productivity of Go-Jek Driver At PT . Go-Jek Indonesia. Journal of Research in 
Business and Management.

Rödiger, M., Plaßmann, S., \& Hamm, U. (2016). Organic consumers' price knowledge, willingness-to-pay and purchase decision. British Food Journal, 118(11), 2732-2743. https://doi.org/10.1108/BFJ-04-2016-0164

Rosyid, A. N., Djoko W, H., \& Widayanto. (2013). Pengaruh Kualitas Produk , Citra Merek , Harga dan Iklan Terhadap Keputusan Pembelian Sepeda Motor Honda Revo ( Studi Kasus pada Konsumen Sepeda Motor Honda Revo Astra Motor Kebumen ). Diponegoro Journal of Social and Politic, 1-8.

Setiawan, E. B., Wati, S., Wardana, A., \& Ikhsan, R. B. (2020). Building trust through customer satisfaction in the airline industry in Indonesia: Service quality and price fairness contribution. Management Science Letters, 10(5), 1095-1102. https://doi.org/10.5267/j.msl.2019.10.033

Setyadi, D. A. (2017). Build Customer Loyalty with CRM and Brand Image (Case Study on Giant Citra Raya). IOSR Journal of Business and Management, 19(01), 35-42. https://doi.org/10.9790/487x-1901043542

Sitio, T., \& Ali, H. (2019). Patient Satisfaction Model and Patient Loyalty: Analysis of Service Quality and Facility (Case Study at Rawamangun Special Surgery Hospital). Scholars Bulletin. https://doi.org/10.36348/sb.2019.v05i10.002

SiVARAM, M., Hudaya, A., \& Ali, H. (2019). Building a Purchase and Purchase Decision: Analysis of Brand Awareness and Brand Loyalty. Dinasti International Journal of Education Management And Social Science, 1(2), 235-248. https://doi.org/10.31933/DIJEMSS

Suhaily, L. (2017). EFFECT OF PRODUCT QUALITY , PERCEIVED PRICE AND BRAND IMAGE ON PURCHASE DECISION ( Study On Japanese Brand Electronic Product ). XXI(02), 179-194.

Sulistiorini, M. S., \& Ali, H. (2017). Customer satisfaction model: Product analysis, price, promotion and distribution (case study at PT Integrasia Utama). International Journal of Applied Business and Economic Research.

Suryana, S. (2010). Metodologi Penelitian. Universitas Pendidikan Indonesia, 58. https://doi.org/10.1007/s13398-014-0173-7.2

Susanty, A., Bakhtiar, A., \& Suliantoro, H. (2016). 6 atisfaction on 7 rust and / oyalty of, ndividual) armers to 'airy \& ooperative Case 6 tudy ' airy 6 upply \& hain in Boyolali. 104-108.

Thanh Nguyen, P., Ali, H., \& Agung Hudaya. (2019). MODEL BUYING DECISION AND REPEAT PURCHASE: PRODUCT QUALITY ANALYSIS (Case Study of Bank Permata Syariah Jakarta KPR Financing Customers). Dinasti International Journal of Management Science. https://doi.org/10.31933/dijms.v1i1.29

Yen, Y. S. (2019). Exploring the synergy effect of trust with other beliefs in television shopping. Management Decision, 58(3), 428-447. https://doi.org/10.1108/MD-11-20160814

Yu, C. C., Lin, P. J., \& Chen, C. S. (2013). How brand image, country of origin, and selfcongruity influence internet users' purchase intention. Social Behavior and Personality, 41(4), 599-611. https://doi.org/10.2224/sbp.2013.41.4.599 
Yunita, D., \& Ali, H. (2017). Model of Purchasing Decision ( Renting ) of Generator Set : Analysis of Product Quality, Price an Service at PT . Hartekprima Listrindo.

Economics, Business and Management. https://doi.org/10.21276/sjebm.2017.4.11.12

Zhao, J. Di, Huang, J. S., \& Su, S. (2019). The effects of trust on consumers' continuous purchase intentions in $\mathrm{C} 2 \mathrm{C}$ social commerce: A trust transfer perspective. Journal of Retailing and Consumer Services, 50(January), 42-49.

https://doi.org/10.1016/j.jretconser.2019.04.014 